\title{
Analytical Investigation of the Flexural Capacity of Precast Concrete Frames with Hybrid Joints
}

\author{
Ji-Hun Kim, ${ }^{1}$ Won-Kee Hong $\mathbb{D}^{1}{ }^{1}$ Hee-Cheul Kim, ${ }^{1}$ and Seong-Kyum Kim ${ }^{2}$ \\ ${ }^{1}$ Department of Architectural Engineering, Kyung Hee University, Yongin 17104, Republic of Korea \\ ${ }^{2}$ Research Institute for Mega Structures, Korea University, Engineering Building, Seoul 02841, Republic of Korea \\ Correspondence should be addressed to Won-Kee Hong; hongwk@khu.ac.kr
}

Received 19 October 2018; Revised 25 December 2018; Accepted 10 January 2019; Published 27 February 2019

Academic Editor: Roberto Nascimbene

Copyright (c) 2019 Ji-Hun Kim et al. This is an open access article distributed under the Creative Commons Attribution License, which permits unrestricted use, distribution, and reproduction in any medium, provided the original work is properly cited.

This study aims to evaluate flexural strength based on the inelastic neutral axis calculated from all stress states of the proposed precast composite columns with hybrid beam-column joints, which facilitate the erection of concrete precast frames in a similar manner to that used for steel frames. It was also shown analytically that hybrid joints with headed studs contribute significantly to the flexural moment capacity and effectively increase the flexural structural performance of precast composite columns. The strain compatibility-based analytical results were compared with test data, showing results with an error of less than $8 \%$ at the critical section for the maximum load limit state of specimens. It is observed that the strength contributed by steel sections and headed studs increased by $30 \%$ and $35 \%$ at the yield limit state and maximum load limit, respectively, reducing the dependence on rebars. The total contribution of the headed studs was as large as $12.2 \%$ (average of the two layers of headed studs) at the maximum load limit state, whereas the strength provided by the tensile rebars decreased from $90.5 \%$ to $63.9 \%$ for the specimen with headed studs at the maximum load limit state.

\section{Introduction}

1.1. Research Background. Recently, beam-column moment connections have gained popularity as a modular construction technology. The interaction of structural steel and reinforced concrete materials has been proven to be both economical and constructible. In conventional practice, however, structural steel and reinforced concrete components are not integrated; thus, the potential of the efficient structural system resulting from the combination of both materials is not being realized. Many believe that their combination offers benefits over pure steel or pure concrete systems. From the construction viewpoint, concrete makes the structure more economical to build, whereas structural steel offers an efficient vertical construction [1]. Structurally, the joint connections between steel beams and reinforced concrete columns have demonstrated good strength, stiffness retention, and excellent energy dissipation when subjected to large load reversals [2, 3]. Additionally, these joints demonstrate a desirable ductility and energy dissipation capacity, indicating good structural performance in earthquake zones [4]. Experimental investigations have been undertaken to characterize the seismic behavior of hybrid composite members subjected to seismic loads [5-8]. Annan et al. [9] evaluated the structural performance of modular steel-braced frames under reversed cyclic loading. They found that the overall structural performance of the entire frame primarily depends on the frame configuration, including its connections. In addition, their paper described the strength, stiffness, inelastic force, inelastic deformation, and energy dissipation characteristics of the modular system. Similar observations were made in a recent study conducted by Wang et al. [10]. Five specimens were tested under low reversed cyclic loadings to investigate the structural behavior of steel-concrete composite joints. Their findings demonstrated that steel-concrete composite joints could bear larger seismic loads. Based on experimental investigations, ParraMontesinos et al. [11] proposed a design procedure for hybrid composite frames. The tested specimens were effective in controlling joint deformation and damage, resulting in the formation of plastic hinges at the beam ends. In previous studies, numerical and analytical studies also were conducted to assess the structural performance of hybrid composite connections under various types of loads [6, 12-14]. Using tests and theoretical data, Bjorhovde et al. [15] classified joint 
connections in terms of strength, stiffness, and ductility requirements. They concluded that the use of their classification system was likely to have a wide practical impact. Tagawa et al. [8] presented an analytical model to predict the behavior of steel moment-resisting frames under repeated and reversed horizontal loading. It was found that their analytical prediction closely matched the experimental investigation, and a hysteresis rule was developed based on their simplified model. Sheikh et al. [1] outlined recommendations for the design of the aforementioned beam-column moment connections between steel beams and concrete columns, which are intended to replace traditional practices. In their recommendations, they detailed considerations for structural steel and reinforcing bars.

1.2. Research Motivations and Significance. Previously, the authors developed the use of steel joint connections for precast concrete frames to provide constructability and assembly times similar to those of steel frames [17]. The joints of the precast columns were made of steel plates, headed studs, and wide flange steel beams, with horizontal steel brackets. The beam-column joint was then assembled by embedding an $\mathrm{H}$-beam in the column where the steel beams are connected. The present study aimed to analytically investigate the strength and ductility of novel beamcolumn joints with embedded steel sections having headed studs by analytically exploring the structural performance of precast concrete frames with hybrid joints. The load path within the hybrid joints was identified; this contributes to the effective increase of flexural moment capacity and the flexural structural performance of precast frames. The accurate inelastic neutral axis of precast composite columns with steel joints and headed studs also was located based on strain compatibilities to propose a simplified analytical procedure for estimating the influence of joint steel sections and headed studs on the flexural load-bearing capacity.

\section{Test Overview}

An experimental investigation of the behavior, crack patterns, and flexural moment capacity of columns with steel sections at joints was conducted in the previous study of the authors [17]. Tests were performed with monolithic concrete columns with and without steel joints. A section of the concrete column with axially embedded steel was used to investigate the influence of the steel joint on the flexural capacity increase of the concrete columns. Table 1 [17] lists the specimens' joint details and dimensions. The column specimens for the analytical study are shown in Figure 1 [17]. Specimens \#1 and \#2 were constructed using conventional monolithic concrete columns without and with steel joints, respectively. However, in Specimen \#3, a steel column running along its entire length was encased in concrete with rebars. The readers are referred to Figure 5 of the previous work by the authors [17] for the fabrication of Specimen \#2. The instrumented specimen and test setup using actuators with a capacity of $1,000 \mathrm{kN}$ and strain gauges are shown in Figure 5 of the previous work by the authors [17]. Specimen details and materials can be found in the previous work by the authors [17]. Instrumented specimens ready for testing are shown in Figure 8 of the previous work by the authors [17], including an actuator with a capacity of $1000 \mathrm{kN}$ (maximum stroke of $300 \mathrm{~mm}$ ) located $1.5 \mathrm{~m}$ from the slab surface and foundation. The effects of seismic loads were simulated as suggested by the American Institute of Steel Construction (AISC) for qualifying beam-tocolumn moment connections [18]. The test was run under displacement control and followed by the cyclic loading protocol of two or three cycles for each stroke length, as depicted in Figure 9 of the previous work by the authors [17].

\section{Derivation of the Analytical Equations}

The stress level of the precast specimens with hybrid joints during the test is defined in Figure 2. Figure 3 presents the correct stress distribution for each limit state for the specimens. A neutral axis satisfying the equilibrium from all possible stress states of the specimens shown in Tables 2 and 3 was found. All locations of the neutral axis and corresponding stress states of the sections were investigated to identify the correct neutral axis for each limit state of all specimens. The eight different stress states were investigated, and the stress states of Specimens \#2 and \#3 were identified as M-CRnyT1SyT2SyTRy and M-T1FnyT2FpTWppCRnyTRy, respectively, for the stress state based on the correct location of the neutral axis and corresponding stress states of composite structural components at the maximum load limit state.

The equilibrium equation of Specimen \#3 at the maximum load limit state formulated in terms of the neutral axis is given by M-\#8 (T1FnyT2FpTWppCRnyTRy) and by the following equation:

$$
\begin{aligned}
\alpha f_{\mathrm{c}}^{\prime} b c+A_{\mathrm{s}}^{\prime} E_{\mathrm{s}} \frac{\varepsilon_{\mathrm{c}}}{C}\left(c-d^{\prime \prime}\right)= & A_{\mathrm{s}} f_{\mathrm{y}}+A_{\mathrm{f}} F_{\mathrm{y}}+A_{\mathrm{wp}} F_{\mathrm{y}}+\frac{1}{2} A_{\mathrm{wny}} E_{\mathrm{s}} \frac{\varepsilon_{\mathrm{c}}}{c} \\
& \cdot\left[\left(\frac{\varepsilon_{\mathrm{sy}}}{\varepsilon_{\mathrm{c}}} c\right)-\left\{t_{\mathrm{f}}^{\prime}-\left(c-d^{\prime \prime \prime}\right)\right\}\right] \\
& +A_{\mathrm{wny}} E_{\mathrm{s}} \frac{\varepsilon_{\mathrm{c}}}{c}\left\{t_{\mathrm{f}}^{\prime}-\left(c-d^{\prime \prime \prime}\right)\right\},
\end{aligned}
$$

where

$$
\begin{aligned}
& A_{\mathrm{wp}}=t_{\mathrm{w}}\left\{d-\left(c+d^{\prime}+t_{\mathrm{f}}+\frac{\varepsilon_{\mathrm{sy}}}{\mathcal{E}_{\mathrm{c}}} c\right)\right\}, \\
& A_{\mathrm{wny}}=t_{\mathrm{w}}\left[\frac{\varepsilon_{\mathrm{sy}}}{\varepsilon_{\mathrm{c}}} c-\left\{t_{\mathrm{f}}^{\prime}-\left(c-d^{\prime \prime \prime}\right)\right\}\right] .
\end{aligned}
$$

Variables in Equations (1), (3), (4), and (6)-(11) are defined in Figure 4 and Table 4 . The first part of equation (1) represents the compression contributed by the concrete block, and the other part of the equation gives the tension contributed by the tensile elements of the specimen. For the preyield state, yield limit state, maximum load limit state, and failure limit state, the corresponding stress states of the sections were obtained, but one at the maximum load limit state was stated in equation (1) and Figure 5(c). Only one correct neutral axis exists for each section of the specimen's 
TABLE 1: Dimensions and joint details of test specimen columns [17].

Specimen \#1

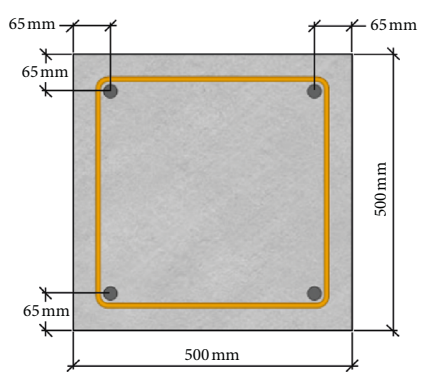

Top rebar Bottom rebar

Hoops

Section size

Design strength

Size of the steel section
Specimens \#2 (joint) and \#3 (entire length)

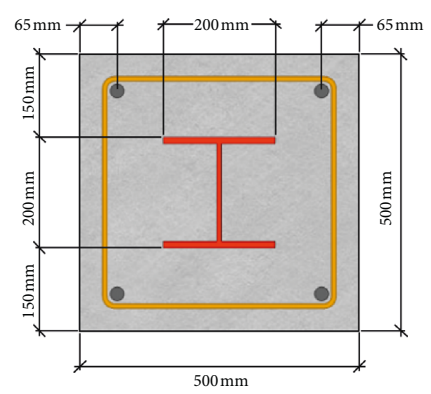

As top $=1013.4 \mathrm{~mm}^{2}(2-\mathrm{HD} 25)$ As bottom $=1013.4 \mathrm{~mm}^{2}(2-\mathrm{HD} 25)$

Hoops=HD13@200

$B=500 \mathrm{~mm}, H=500 \mathrm{~mm}$

$F_{\mathrm{c}}=27 \mathrm{MPa}, F_{\mathrm{y}}=235 \mathrm{MPa}(\mathrm{SM} 400), f_{\mathrm{y}}=400 \mathrm{MPa}$ $H=200 \times 200 \times 8 \times 12$
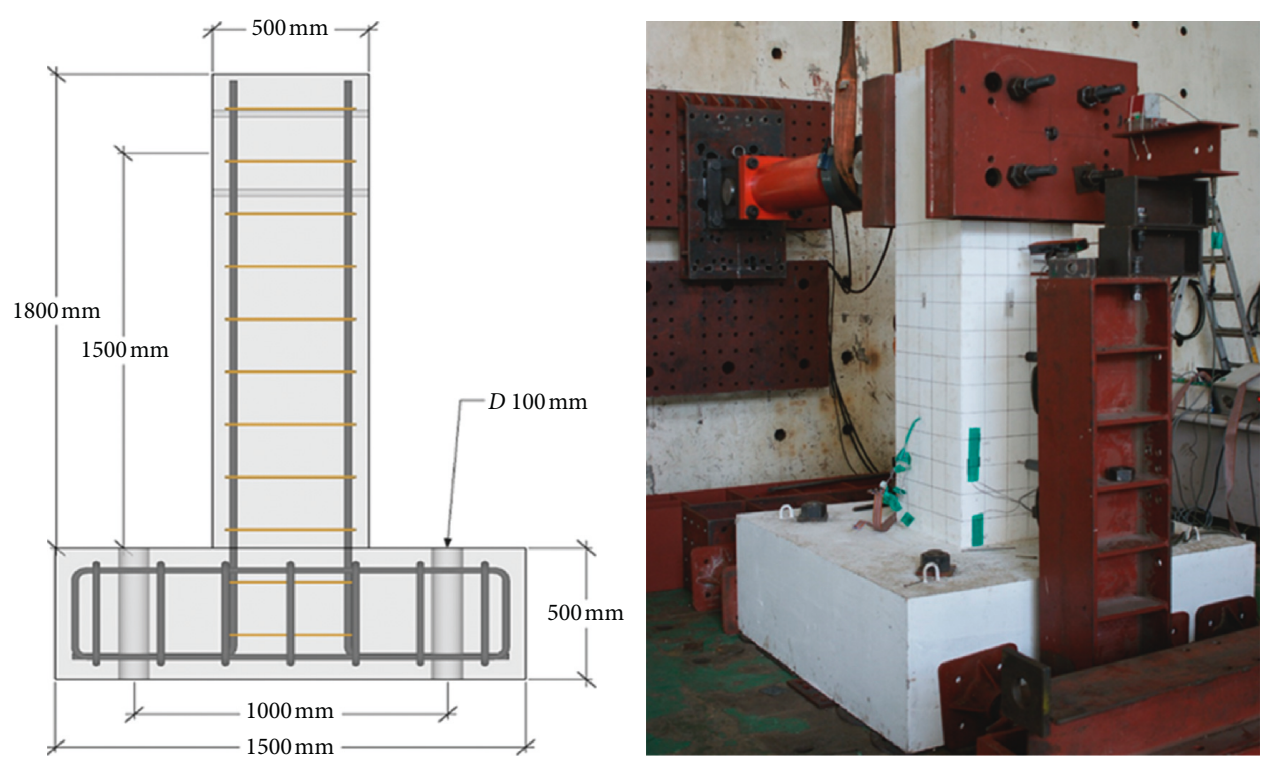

(a)
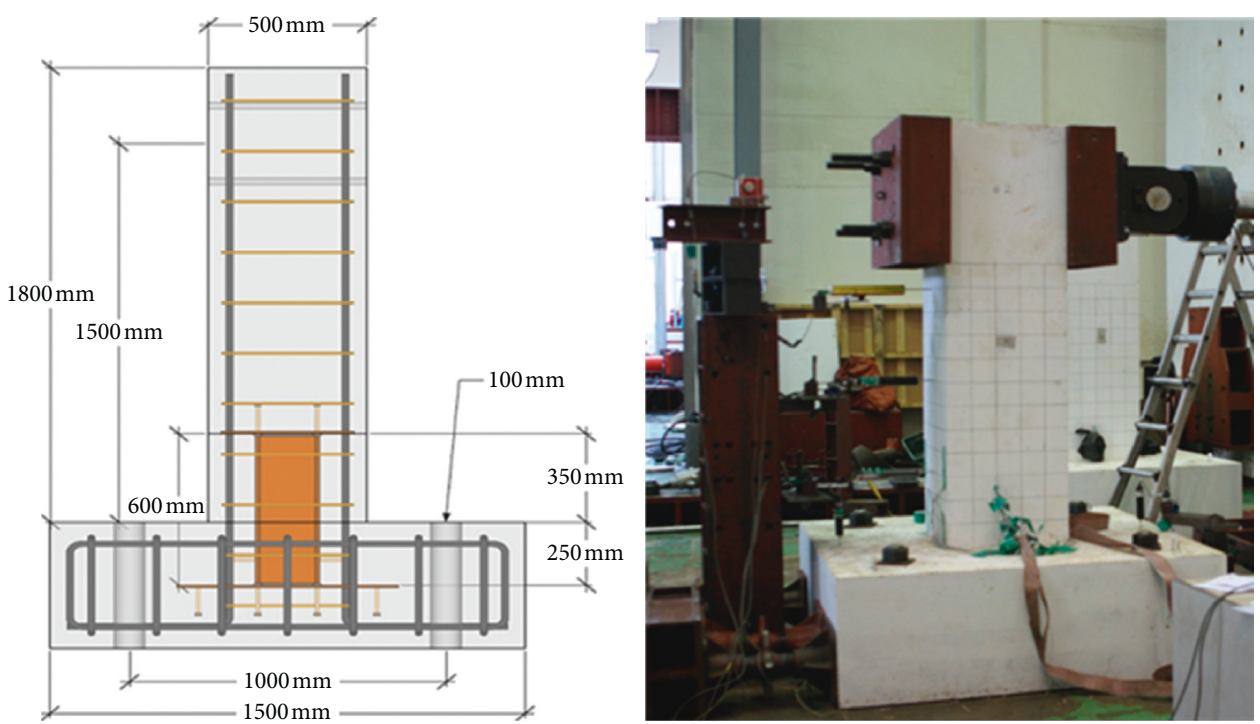

(b)

Figure 1: Continued. 

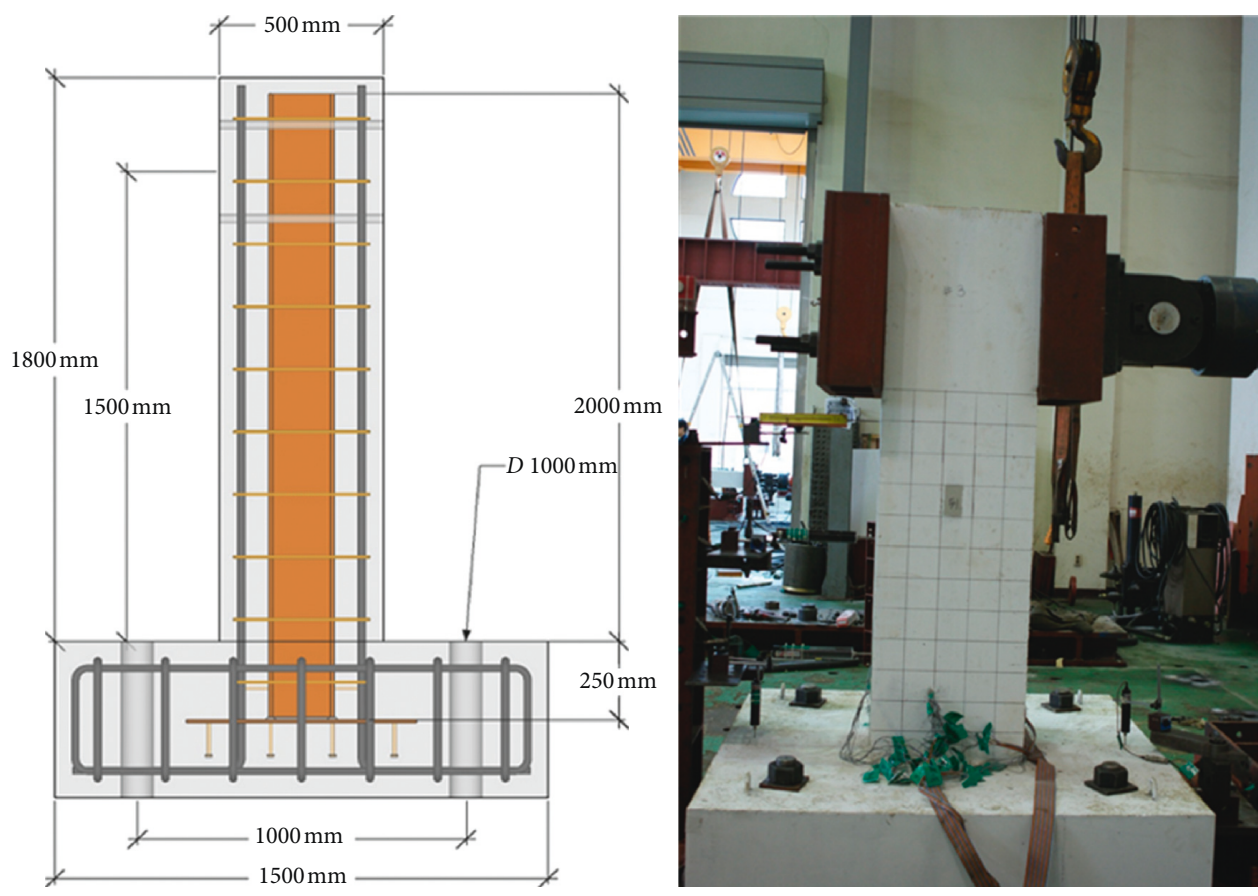

(c)

Figure 1: Column test specimens [17]. (a) Specimen \#1: conventional concrete column. (b) Specimen \#2: column with the steel section and headed studs at the joint. (c) Specimen \#3: concrete column encasing a steel section.

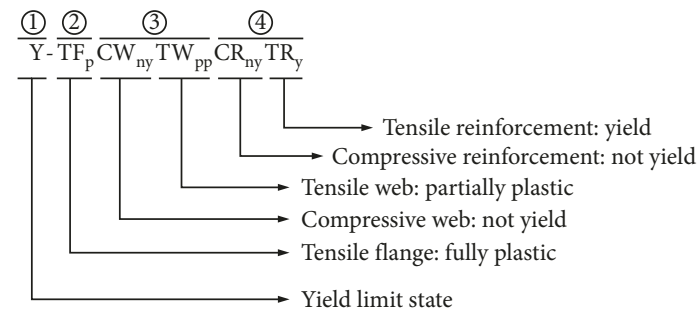

Figure 2: Definition of a stress level.

stress field, which enables accurate analytical analysis and design of precast columns with hybrid joints. Equation (3) is given in terms of the neutral axis and was derived from equation (1), which then was used in Equation (4) to calculate the flexural moment capacity at the maximum load limit state:

$$
\begin{aligned}
& \left\{\alpha f_{\mathrm{c}}^{\prime} b+t_{\mathrm{w}} F_{\mathrm{y}}\left(1+\frac{\varepsilon_{\mathrm{sy}}}{\varepsilon_{\mathrm{c}}}\right)+\frac{1}{2} t_{\mathrm{w}} \varepsilon_{\mathrm{c}} E_{\mathrm{s}}\left(1+\frac{\varepsilon_{\mathrm{sy}}}{\varepsilon_{\mathrm{c}}}\right)^{2}\right. \\
& \left.\quad-t_{\mathrm{w}} \varepsilon_{\mathrm{c}} E_{\mathrm{s}}\left(1+\frac{\varepsilon_{\mathrm{sy}}}{\varepsilon_{\mathrm{c}}}\right)\right\} c^{2}+\left\{A_{\mathrm{s}}^{\prime} \varepsilon_{\mathrm{c}} E_{\mathrm{s}}+b_{\mathrm{f}} t_{\mathrm{f}}^{\prime} \varepsilon_{\mathrm{c}} E_{\mathrm{s}}-A_{\mathrm{s}} f_{\mathrm{y}}\right. \\
& \left.\quad-A_{\mathrm{f}} F_{\mathrm{y}}-t_{\mathrm{w}} \varepsilon_{\mathrm{c}} E_{\mathrm{s}}\left(1+\frac{\varepsilon_{\mathrm{sy}}}{\varepsilon_{\mathrm{c}}}\right)\left(d^{\prime \prime \prime}+t_{\mathrm{f}}\right)-t_{\mathrm{w}} F_{\mathrm{y}}\left(d-d^{\prime}-t_{\mathrm{f}}^{\prime}\right)\right\} c \\
& \quad+\left\{-A_{\mathrm{s}}^{\prime} \varepsilon_{\mathrm{c}} E_{\mathrm{s}} d^{\prime \prime}-b_{\mathrm{f}} t_{\mathrm{f}}^{\prime} \varepsilon_{\mathrm{c}} E_{\mathrm{s}}\left(d^{\prime \prime \prime}+\frac{t_{\mathrm{f}}^{\prime}}{2}\right)+\frac{1}{2} t_{\mathrm{w}} \varepsilon_{\mathrm{c}} E_{\mathrm{s}}\left(d^{\prime \prime \prime}+t_{\mathrm{f}}^{\prime}\right)^{2}\right\} \\
& \quad=0,
\end{aligned}
$$

and

$$
\begin{aligned}
M_{\mathrm{n}}= & \alpha f_{\mathrm{c}}^{\prime} b c(c-\gamma c)+A_{\mathrm{s}}^{\prime} E_{\mathrm{s}} \frac{\varepsilon_{\mathrm{c}}}{c}\left(c-d^{\prime \prime}\right)^{2}+A_{\mathrm{s}} f_{\mathrm{y}}(d-c) \\
& +A_{\mathrm{f}} F_{\mathrm{y}}\left(d-c-d^{\prime}-\frac{t_{\mathrm{f}}^{\prime}}{2}\right)+\frac{1}{2} A_{\mathrm{wp}} F_{\mathrm{y}}\left(d-c-d^{\prime}-t_{\mathrm{f}}^{\prime}+\frac{\varepsilon_{\mathrm{sy}}}{\varepsilon_{\mathrm{c}}} c\right) \\
& +\frac{1}{2} A_{\mathrm{wny}} E_{\mathrm{s}} \frac{\varepsilon_{\mathrm{c}}}{c}\left\{t_{\mathrm{f}}^{\prime}-\left(c-d^{\prime \prime \prime}\right)\right\}\left\{\frac{\varepsilon_{\mathrm{sy}}}{\varepsilon_{\mathrm{c}}} c+\left(d^{\prime \prime \prime}+t_{\mathrm{f}}^{\prime}-c\right)\right\} \\
& +\frac{1}{6} A_{\mathrm{wny}} E_{\mathrm{s}} \frac{\varepsilon_{\mathrm{c}}}{c}\left\{\frac{\varepsilon_{\mathrm{sy}}}{\varepsilon_{\mathrm{c}}} c+\left(d^{\prime \prime \prime}+t_{\mathrm{f}}^{\prime}-c\right)\right\}\left\{\frac{2 \varepsilon_{\mathrm{sy}}}{\varepsilon_{\mathrm{c}}} c+\left(d^{\prime \prime \prime}+t_{\mathrm{f}}^{\prime}-c\right)\right\},
\end{aligned}
$$

where

$$
\begin{aligned}
& A_{\mathrm{wp}}=t_{\mathrm{w}}\left\{d-\left(c+d^{\prime}+t_{\mathrm{f}}+\frac{\mathcal{E}_{\mathrm{sy}}}{\mathcal{E}_{\mathrm{c}}} c\right)\right\}, \\
& A_{\mathrm{wny}}=t_{\mathrm{w}}\left[\frac{\varepsilon_{\mathrm{sy}}}{\varepsilon_{\mathrm{c}}} c-\left\{t_{\mathrm{f}}^{\prime}-\left(c-d^{\prime \prime \prime}\right)\right\}\right] .
\end{aligned}
$$

Similarly, the calculations of flexural moment capacity at the maximum load limit state of Specimens \#1 and \#2 were based on the stress states M-T1RnyT2Ry of Figure 5(a) and M-CRnyT1SyT2SyTRy of Figure 5(b), respectively, where S from the stress state of M-CRnyT1SyT2SyTRy indicates the stress in headed studs (refer to Figure 5(a) of the previous work by the authors [17]). Figures 3 and 5(b) show that all headed studs yielded in tension, contributing effectively to the flexural capacity of the column. The first part of equations (6) and (9) represents the compression contributed by 


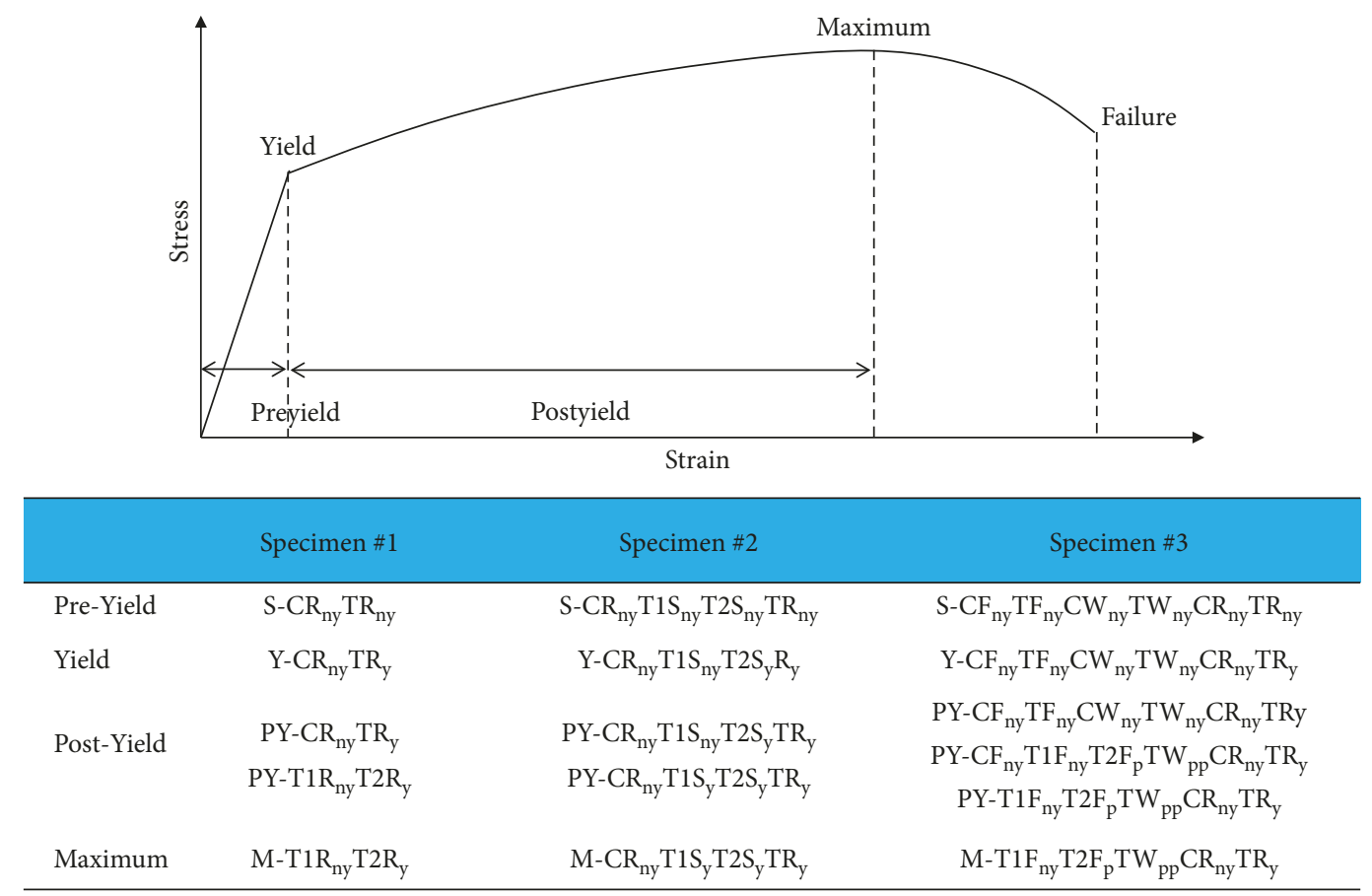

Figure 3: Possible stress states in the preyield state (S), yield limit state (Y), and maximum limit state (M) (Specimens \#1, \#2, and \#3) [19].

TABLe 2: Possible stress states for steel-concrete composite members (wide flange steel, yield, and maximum load state) [19].

Y-\#1 CFnyTFpCWnyTWppCRyTRy

Y-\#2 CFnyTFpCWnyTWppCRnyTRy

Y-\#3 CFnyTFppCWnyTWnyCRyTRy

Y-\#4 CFnyTFppCWnyTWnyCRnyTRy

Y-\#5 CFnyTFnyCWnyTWnyCRyTRy

Y-\#6 CFnyTFnyCWnyTWnyCRnyTRy

Y-\#7 CFnyT1FnyT2FnyTWnyCRnyTRy

Y-\#8 CFnyT1FnyT2FnyTWnyCRyTRy

Y-\#9 T1FnyT2FnyTWnyCRnyTRy

TABLE 3: Equilibria of all possible stress states for steel-concrete composite members (wide flange steel and maximum load state) [19].
M-\#1 CFpTFpCWppTWppCRyTRy M-\#2 CFpTFpCWppTWppCRnyTRy M-\#3 CFppTFpCWnyTWppCRyTRy M-\#4 CFppTFpCWnyTWppCRnyTRy M-\#5 CFnyTFpCWnyTWppCRyTRy M-\#6 CFnyTFpCWnyTWppCRnyTRy M-\#7 CFnyT1FnyT2FpTWppCRnyTRy M-\#8 T1FnyT2FpTWppCRnyTRy

\section{Y-\#10 T1FnyT2FnyTWnyCRyTRy}

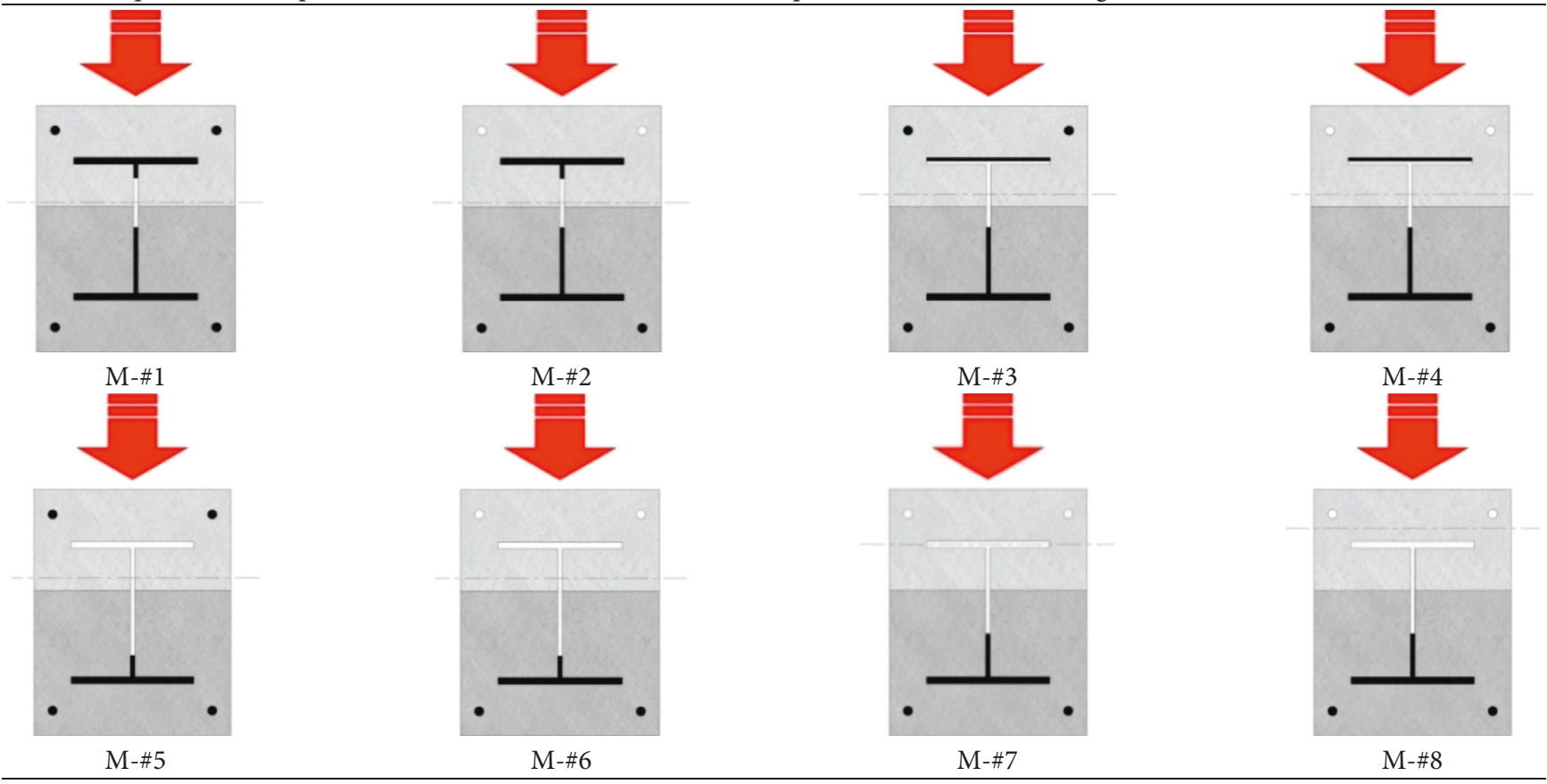




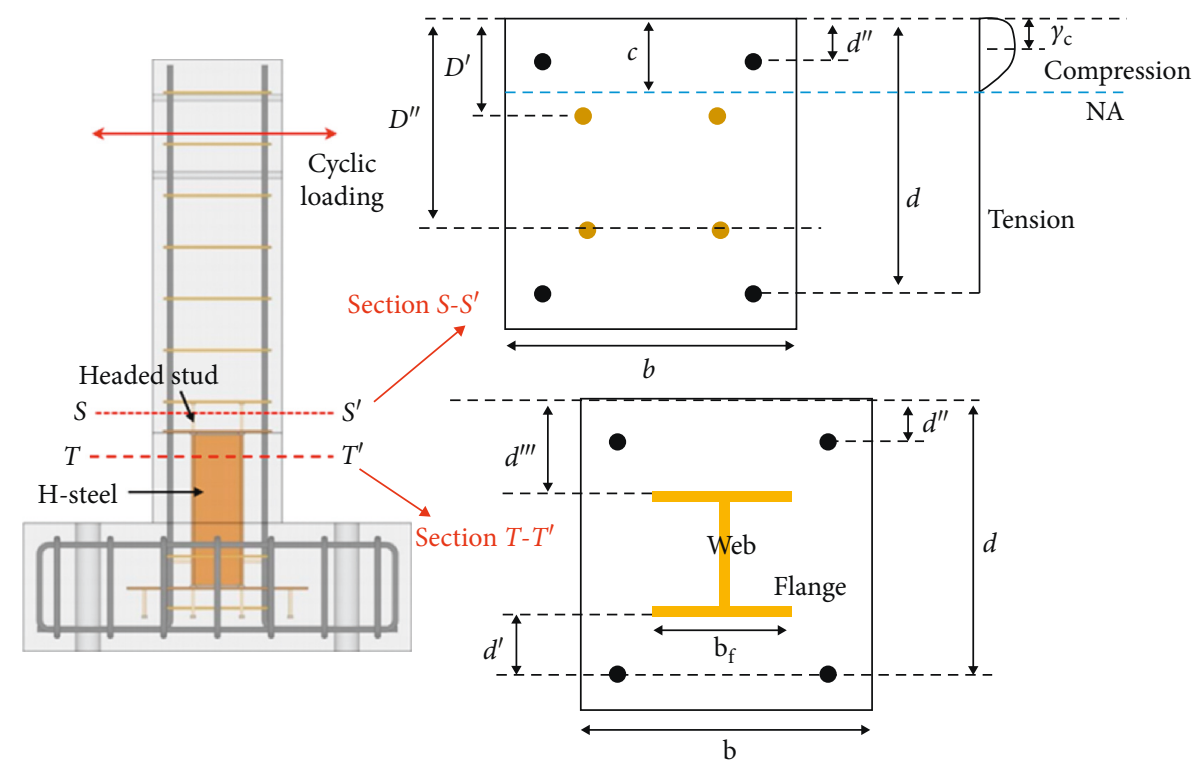

FIgURE 4: Cross sections used to derive equations (1), (3), (4), and (6)-(11).

the concrete block, and the other part of the equations gives the tension contributed by the tensile elements of the specimen for Specimens \#1 and \#2, respectively. equations (7) and (10) are given in terms of the neutral axis and were derived from equations (6) and (9) which, then, were used in equations (8) and (11) to calculate the flexural moment capacity at maximum load limit state for Specimens \#1 and $\# 2$, respectively. Stress and strain distributions were presented in Figures 5(a) to 5(c) for Specimens \#1 to \#3:

$$
\begin{gathered}
\alpha f_{\mathrm{c}}^{\prime} b c+A_{\mathrm{s}}^{\prime} E_{\mathrm{s}} \frac{\varepsilon_{\mathrm{c}}}{c}\left(c-d^{\prime \prime}\right)=A_{\mathrm{s}} f_{\mathrm{y}}, \\
\left(\alpha f_{\mathrm{c}}^{\prime} b\right) c^{2}+\left(A_{\mathrm{s}}^{\prime} E_{\mathrm{s}} \varepsilon_{\mathrm{c}}-A_{\mathrm{s}} f_{\mathrm{y}}\right) c-A_{\mathrm{s}}^{\prime} d^{\prime \prime} \varepsilon_{\mathrm{c}} E_{\mathrm{s}}=0, \\
M_{\mathrm{n}}=\alpha f_{\mathrm{c}}^{\prime} b c(c-\gamma c)+A_{\mathrm{s}}^{\prime} E_{\mathrm{s}} \frac{\varepsilon_{\mathrm{c}}}{c}\left(c-d^{\prime \prime}\right)^{2}+A_{\mathrm{s}} f_{\mathrm{y}}(d-c), \\
\alpha f_{\mathrm{c}}^{\prime} b c+A_{\mathrm{s}}^{\prime} E_{\mathrm{s}} \frac{\varepsilon_{\mathrm{c}}}{c}\left(c-d^{\prime \prime}\right)=A_{\mathrm{s}} f_{\mathrm{y}}+A_{\mathrm{s}, \mathrm{s} 1} f_{\mathrm{y}, \mathrm{s}}+A_{\mathrm{s}, \mathrm{s} 2} f_{\mathrm{y}, \mathrm{s}}, \\
\left(\alpha f_{\mathrm{c}}^{\prime} b\right) c^{2}+\left(A_{\mathrm{s}}^{\prime} \varepsilon_{\mathrm{c}} E_{\mathrm{s}}-A_{\mathrm{s}} f_{\mathrm{y}}-A_{\mathrm{s}, \mathrm{s} 1} f_{\mathrm{y}, \mathrm{s}}-A_{\mathrm{s}, \mathrm{s} 2} f_{\mathrm{y}, \mathrm{s}}\right) c \\
-A_{\mathrm{s}}^{\prime} d^{\prime \prime} \varepsilon_{\mathrm{c}} E_{\mathrm{s}}=0, \\
M_{\mathrm{n}}=\alpha f_{\mathrm{c}}^{\prime} b c(c-\gamma c)+A_{\mathrm{s}}^{\prime} E_{\mathrm{s}} \frac{\varepsilon_{\mathrm{c}}}{c}\left(d^{\prime \prime}-c\right)^{2}+A_{\mathrm{s}} f_{\mathrm{y}}(d-c) \\
+A_{\mathrm{s}, \mathrm{s} 1} f_{\mathrm{y}, \mathrm{s}}\left(D^{\prime}-c\right)+A_{\mathrm{s}, \mathrm{s} 2} f_{\mathrm{y}, \mathrm{s}}\left(D^{\prime \prime}-c\right) .
\end{gathered}
$$

\section{Contribution of Elements to the Total Moment Strength}

Figures 5(a) and 5(b) represent strains and corresponding stress distributions at the maximum load limit state for Specimens \#1 and \#2, respectively. Stresses and forces for Specimen \#3 also were calculated in Figure 5(c), based on the assumption that concrete reached the maximum usable strain of 0.003 [20]. Forces in Figure 5(c) for Specimen \#3 were equilibrated and rearranged in terms of the neutral axis (c), as shown in equation (3). Using equation (3), the neutral axis of Specimen \#3 was located at $145.7 \mathrm{~mm}$ from the compressive face of the section. In this stress state, Figure 5(c) shows that the neutral axis is located between the upper steel flange and the upper rebar elements, indicating that the lower steel flange, lower rebar elements, and lower part of the steel web were fully plasticized, as represented by the solid black color and T1FnyT2FpTWppCRnyTRy. The nominal moment strength calculated by equation (4) was $521.99 \mathrm{kN} \cdot \mathrm{m}$ for Specimen \#3, which is $21.2 \%$ greater than that of the yield limit state. The strain and stress of elements of the specimens and contribution of elements to the total moment strength are presented in Tables 5-7. The abbreviations in Tables 5-7 are defined in Table 4 . Table 8 summarizes the yield and nominal moment capacity of the specimens.

In Table 5, the tensile steel flange, tensile rebar, and concrete of Specimen \#3 contributed 34.7\% (181.0 kN.m), $25.7 \%(134.3 \mathrm{kN} \cdot \mathrm{m})$, and $25.6 \%(133.9 \mathrm{kN} \cdot \mathrm{m})$ of the total moment strength, respectively. The contribution of the headed studs in Specimen \#2, which provide additional flexural resistance to the capacity of the column, is described in Figure 5(b), which depicts the critical section for the analytical evaluation of the flexural strength of Specimen \#2. A similar procedure was used to estimate the strength offered by the headed studs at the maximum load state based on the stress-strain field. The neutral axis of Specimen \#2 also is shown in Figure 5(b). The contribution of the headed studs to the total resistance of the column is as large as $12.2 \%$ (average of the two layers of headed studs) at the maximum load limit state, as shown in Table 6. These headed studs are subjected to tensile stress, as shown in Figure 5(b) and Table 2. A similar trend is found at the yield limit state, where the contribution of the headed studs is calculated to be $16.5 \%$. The flexural moment capacity of the conventional 
TABLE 4: Variables used in equations (1), (3), (4), and (6)-(11) and Tables 5-7 [19].

\begin{tabular}{|c|c|}
\hline Variable & Nomenclature \\
\hline$\alpha$ & Stress factor \\
\hline$f_{\mathrm{c}}^{\prime}$ & Concrete compressive strength (MPa) \\
\hline$h$ & Column depth (mm) \\
\hline$b$ & Column width (mm) \\
\hline$c$ & Depth of the concrete compressive zone (mm) \\
\hline$d$ & Column effective depth (mm) \\
\hline$A_{\mathrm{s}}^{\prime}$ & Area of the rebar in compression $\left(\mathrm{mm}^{2}\right)$ \\
\hline$A_{s}^{s}$ & Area of the rebar in tension $\left(\mathrm{mm}^{2}\right)$ \\
\hline$f_{\mathrm{y}}$ & Yield stress of the rebar (MPa) \\
\hline$F_{y}$ & Yield stress of steel (MPa) \\
\hline$A_{\mathrm{w}}^{\mathrm{y}}$ & Area of the steel web $\left(\mathrm{mm}^{2}\right)$ \\
\hline$A_{\mathrm{f}}$ & Area of the steel flange $\left(\mathrm{mm}^{2}\right)$ \\
\hline$\varepsilon_{\mathrm{s}}$ & Yield strain \\
\hline$\varepsilon_{\mathrm{c}}$ & Concrete strain of 0.003 \\
\hline$\gamma$ & Centroid factor \\
\hline$\varepsilon_{\text {sy }}$ & Yield strain of steel \\
\hline$A_{\mathrm{f}}^{\prime \prime}$ & Area of the flange in compression $\left(\mathrm{mm}^{2}\right)$ \\
\hline$F_{c}$ & Compressive force (concrete) $(\mathrm{kN})$ \\
\hline$F_{\mathrm{t}}^{\prime}$ & Compressive force (rebar) $(\mathrm{kN})$ \\
\hline$M_{\mathrm{t}}$ & Moment contributed by the rebar in tension $(\mathrm{kN} \cdot \mathrm{m})$ \\
\hline$F_{\mathrm{t} 1}$ and $F_{\mathrm{t} 2}$ & $\begin{array}{l}\text { Tensile force in rebars (first and second layers) } \\
\qquad(\mathrm{kN})\end{array}$ \\
\hline$F_{\mathrm{t} 1 \mathrm{~s}}$ and $F_{\mathrm{t} 2 \mathrm{~s}}$ & $\begin{array}{l}\text { Tensile force in headed studs (first and second } \\
\text { layers) }(\mathrm{kN})\end{array}$ \\
\hline$M_{\text {flange }}^{\prime}$ & $\begin{array}{l}\text { Moment contributed by the flange in compression } \\
\qquad(\mathrm{kN} \cdot \mathrm{m})\end{array}$ \\
\hline$M_{\text {web }}^{\prime}$ & $\begin{array}{c}\text { Moment contributed by the steel web in } \\
\text { compression }(\mathrm{kN} \cdot \mathrm{m})\end{array}$ \\
\hline$d^{\prime}$ & $\begin{array}{l}\text { Distance from the tensile rebar to the tensile flange } \\
\qquad(\mathrm{mm})\end{array}$ \\
\hline$d^{\prime \prime}$ & $\begin{array}{l}\text { Distance from the extreme compressive layer of } \\
\text { concrete to the compressive rebar (mm) }\end{array}$ \\
\hline$H$ and $B$ & Steel width and steel depth $(\mathrm{mm})$ \\
\hline$d^{\prime \prime \prime}$ & $\begin{array}{l}\text { Distance from the extreme compressive layer of } \\
\text { concrete to the compressive steel flange (mm) }\end{array}$ \\
\hline$t_{\mathrm{f}}^{\prime}$ & Thickness of the steel flange in compression ( $\mathrm{mm})$ \\
\hline y & Yield \\
\hline ny & Not yield \\
\hline $\mathrm{P}$ & Plastic \\
\hline $\mathrm{p}_{\mathrm{p}}$ & Partially plastic \\
\hline$E_{\mathrm{s}}$ & Young's modulus of steel (MPa) \\
\hline$t_{\mathrm{f}}$ & Thickness of the steel flange in tension (mm) \\
\hline$t_{\mathrm{w}}$ & Thickness of the steel web in tension (mm) \\
\hline$b_{\mathrm{f}}$ & Width of the steel flange $(\mathrm{mm})$ \\
\hline$D^{\prime}$ & $\begin{array}{l}\text { Distance from the extreme compressive layer of } \\
\text { concrete to the first layer of the headed stud (mm) } \\
\text { (Figure } 4)\end{array}$ \\
\hline$D^{\prime \prime}$ & $\begin{array}{l}\text { Distance from the extreme compressive layer of } \\
\text { concrete to the second layer of the headed stud } \\
\qquad(\mathrm{mm}) \text { (Figure } 4)\end{array}$ \\
\hline$\varepsilon_{\mathrm{y}}$ & Yield strain of the rebar \\
\hline$A_{\mathrm{f}}$ and $A_{\mathrm{ss}}$ & $\begin{array}{l}\text { Area of the flange in tension and area of the headed } \\
\text { stud }\left(\mathrm{mm}^{2}\right)\end{array}$ \\
\hline$M_{\mathrm{c}}$ & $\begin{array}{l}\text { Moment contributed by concrete in compression } \\
\qquad(\mathrm{kN} \cdot \mathrm{m})\end{array}$ \\
\hline$F_{\mathrm{t}}$ & Tension force (rebar) $(\mathrm{kN})$ \\
\hline$M_{\mathrm{t}}^{\prime}$ & $\begin{array}{l}\text { Moment contributed by the rebar in compression } \\
\qquad(\mathrm{kN} \cdot \mathrm{m})\end{array}$ \\
\hline$M_{\mathrm{t} 1}$ and $M_{\mathrm{t} 2}$ & $\begin{array}{c}\text { Moments contributed by rebars (first and second } \\
\text { layers) }(\mathrm{kN} \cdot \mathrm{m})\end{array}$ \\
\hline
\end{tabular}

TABle 4: Continued.

\begin{tabular}{lc}
\hline Variable & Nomenclature \\
\hline$M_{\mathrm{t} 1 \mathrm{~s}}$ and $M_{\mathrm{t} 1 \mathrm{~s}}$ & $\begin{array}{r}\text { Moments contributed by headed studs (first and } \\
\text { second layers) }(\mathrm{kN} \cdot \mathrm{m})\end{array}$ \\
$\begin{array}{c}\text { Moment contributed by the steel flange in tension } \\
(\mathrm{kN} \cdot \mathrm{m})\end{array}$ \\
$\begin{array}{c}M_{\text {flange }} \\
\text { Moment contributed by the steel web in tension } \\
(\mathrm{kN} \cdot \mathrm{m})\end{array}$ \\
\hline
\end{tabular}

monolithic concrete column, Specimen \#1, at the maximum load limit state is presented in Table 7. Equations (1), (3), (4), and (6)-(11) were used to calculate flexural strength at both yield and maximum load limit states. The strength of Specimen \#2 is $30 \%$ and $35 \%$ larger than that of Specimen \#1 for the yield limit and maximum load limit states, respectively. This can be attributed to the additional flexural capacity provided by the joint steel sections with headed studs, indicating that the contribution of headed studs with steel sections should be explored. The flexural strength provided by the tensile rebar decreases from $90.5 \%$ for Specimen \#1 (Table 7) to $63.9 \%$ for Specimen \#2 (Table 6) at the maximum load limit state; therefore, the strength contributed by joint steel and headed studs can decrease the dependence on rebars. Figure 5(b) for Specimen \#2 shows the contribution of the steel section and headed studs to deepening the compressive zone of the concrete block, from $53.06 \mathrm{~mm}$ (Specimen \#1) to $70.14 \mathrm{~mm}$ (Specimen \#2), allowing concrete to contribute more to the flexural strength of the column; this resulted in the concrete contributing $9.0 \%, 11.6 \%$, and $25.6 \%$ to the strengths of Specimens \#1, \#2, and \#3, respectively, at the maximum load limit state.

\section{Analytical Load-Strain Relationship}

Tables 9-11 present moment-strain relationships of the specimens calculated based on the equations presented in Section 3 for all limit states. Neutral axes also are listed, moving down towards the bottom of the section as the tensile rebars and steel section yielded. Figure 6 compares the analytical load-strain relationships to the measured data based on Strain Gauge \#20 for the three specimens. Figure 6 also demonstrates that the analytical data matched the test readings well, including in Specimen $\# 2$, which has a steel section and headed studs in the joint.

\section{Conclusions}

In this study, the contribution of headed studs was explored analytically and compared with experimental investigations. The contributions of steel sections and headed studs in the joints of conventional reinforced concrete columns were demonstrated based on the proposed analytical equations. In the analytical calculations, the maximum usable concrete strain in many design codes was assumed to be 0.003 from the unconfined Kent-Park model; however, concrete can sustain much larger strains beyond 0.01 when the steel section and headed studs are integrated with concrete. In the 

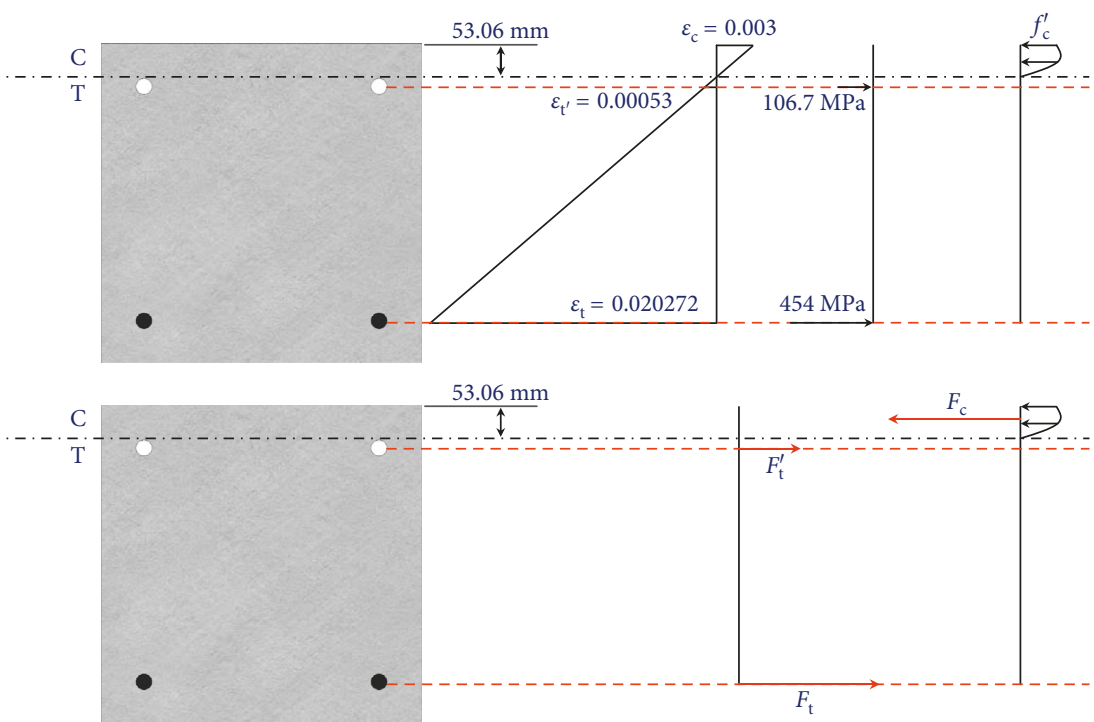

(a)

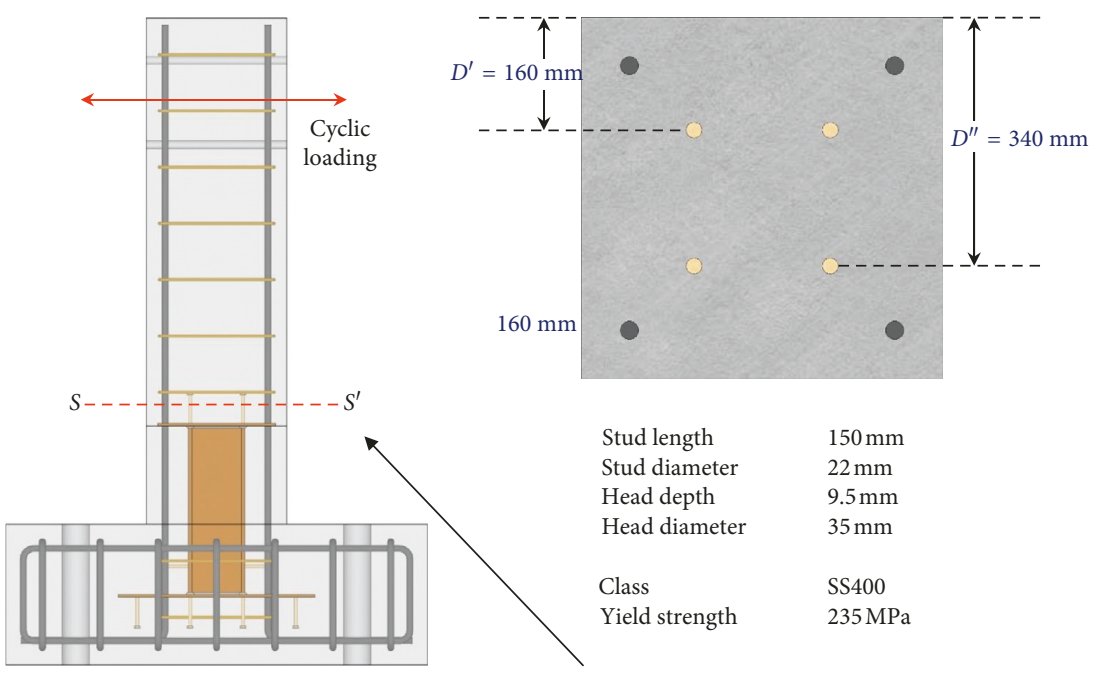

Critical section for analytical estimation
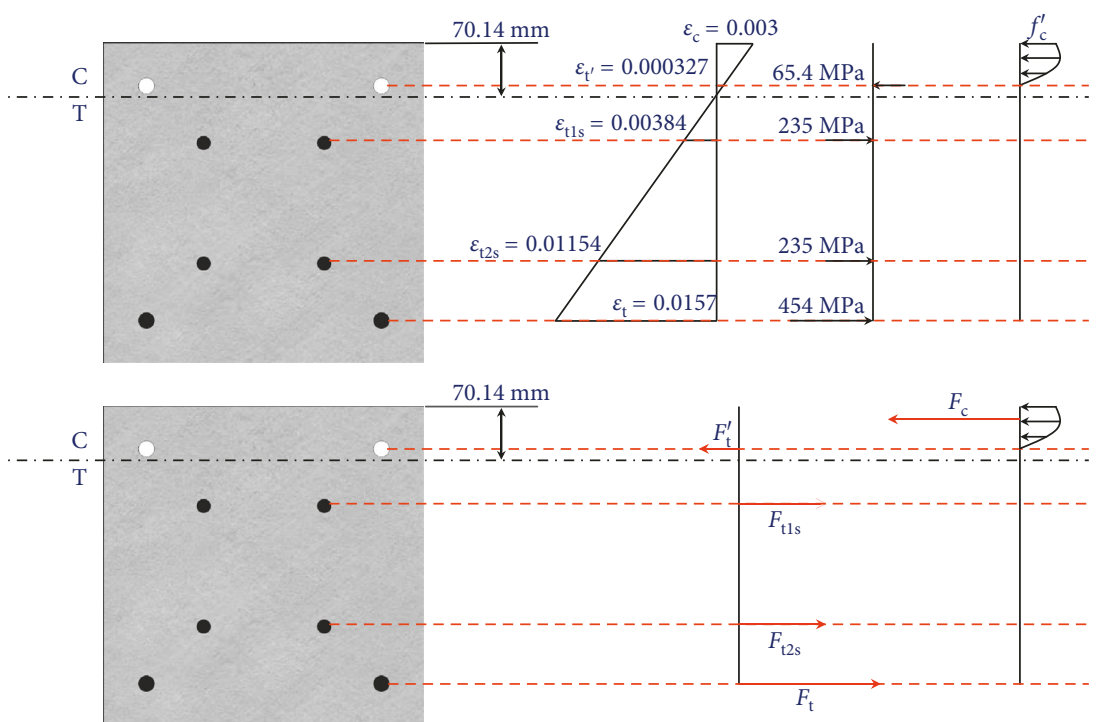

(b)

FIGURE 5: Continued. 


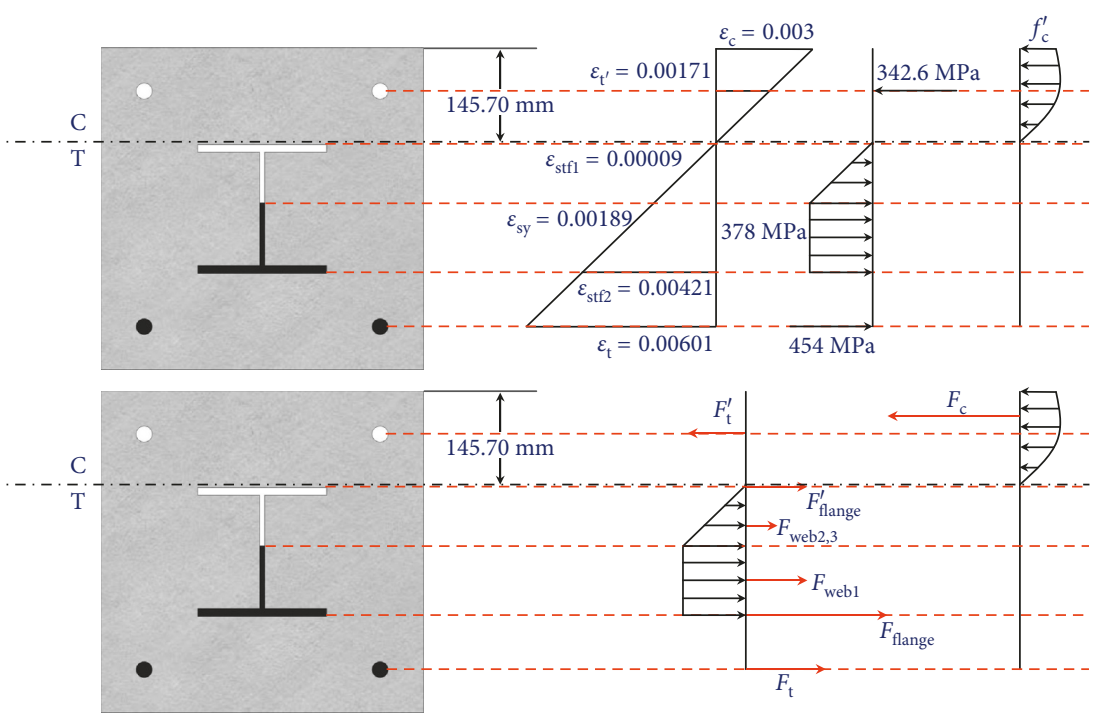

(c)

FIGURE 5: Strain and stress distribution of the specimens [19]. (a) Strain and stress state at the maximum load limit state of Specimen \# 1 (MT1RnyT2Ry); (b) Specimen \#2 (M-CRnyT1SyT2SyTRy); (c) Specimen \#3 (T1FnyT2FpTWppCRnyTRy).

Table 5: Flexural moment capacity at the maximum load state (Specimen \#3) [19].

\begin{tabular}{|c|c|c|c|c|c|c|c|c|c|}
\hline \multicolumn{10}{|c|}{ Maximum load state (M-T1FnyT2FpTWppCRnyTRy) } \\
\hline $\begin{array}{l}h \\
500 \mathrm{~mm}\end{array}$ & $\begin{array}{c}b \\
500 \mathrm{~mm}\end{array}$ & $\begin{array}{c}F_{\mathrm{y}} \\
378 \mathrm{MPa}\end{array}$ & $\begin{array}{c}f_{\mathrm{y}} \\
454 \mathrm{MPa}\end{array}$ & $\begin{array}{c}\mathcal{E}_{\text {sy }} \\
0.00189\end{array}$ & \multicolumn{2}{|c|}{$\begin{array}{c}\mathcal{E}_{\mathrm{y}} \\
0.00227\end{array}$} & $\begin{array}{c}E_{\mathrm{s}} \\
200000 \mathrm{MPa}\end{array}$ & $\begin{array}{c}f_{\mathrm{c}}^{\prime} \\
28.14 \mathrm{MPa}\end{array}$ & $\begin{array}{c}\mathcal{E}_{\mathrm{c}} \\
0.003\end{array}$ \\
\hline $\begin{array}{l}h \\
200 \mathrm{~mm} \\
\end{array}$ & $\begin{array}{c}b \\
200 \mathrm{~mm}\end{array}$ & $\begin{array}{c}t_{\mathrm{w}} \\
8.0 \mathrm{~mm}\end{array}$ & $\begin{array}{c}t_{\mathrm{f}}^{\prime} \\
12.0 \mathrm{~mm}\end{array}$ & $\begin{array}{c}t_{\mathrm{f}} \\
12.0 \mathrm{~mm}\end{array}$ & \multicolumn{2}{|c|}{$\begin{array}{c}A_{\mathrm{f}}^{\prime} \\
2400 \mathrm{~mm}^{2}\end{array}$} & $\begin{array}{c}A_{\mathrm{f}} \\
2400 \mathrm{~mm}^{2}\end{array}$ & & \\
\hline $\begin{array}{l}A_{\mathrm{s}}^{\prime} \\
1013.4 \mathrm{~mm}^{2}\end{array}$ & $\begin{array}{c}A_{\mathrm{s}} \\
1013.4 \mathrm{~mm}^{2}\end{array}$ & & $\begin{array}{c}d \\
437.5 \mathrm{~mm}\end{array}$ & $\begin{array}{c}d^{\prime \prime \prime} \\
150 \mathrm{~mm}\end{array}$ & \multicolumn{2}{|c|}{$\begin{array}{c}d^{\prime \prime} \\
62.5 \mathrm{~mm}\end{array}$} & $\begin{array}{c}d^{\prime} \\
87.5 \mathrm{~mm}\end{array}$ & $\begin{array}{c}\alpha \\
0.76111 \\
\end{array}$ & $\begin{array}{c}\gamma \\
0.41119\end{array}$ \\
\hline & & & \multicolumn{4}{|c|}{ Compression } & \multicolumn{3}{|c|}{ Tension } \\
\hline $\begin{array}{l}c \\
M \text { (total) } \\
\text { Rebar (compressive) } \\
\text { Tensile flange (top) }\end{array}$ & $\begin{array}{c}145.70 \mathrm{~mm} \\
566.1 \mathrm{kN} \cdot \mathrm{m} \\
0.001713090 \\
0.000088584\end{array}$ & Force & $\begin{array}{c}F_{\mathrm{c}} \\
1560.3 \mathrm{kN} \\
40.9 \%\end{array}$ & $\begin{array}{c}F_{\mathrm{t}}^{\prime} \\
347.2 \mathrm{kN} \\
9.1 \%\end{array}$ & $\begin{array}{c}F_{\text {flange }}^{\prime} \\
0.0 \mathrm{kN} \\
0.0 \%\end{array}$ & $\begin{array}{c}F_{\text {web }}^{\prime} \\
0.0 \mathrm{kN} \\
0.0 \%\end{array}$ & $\begin{array}{c}F_{\mathrm{t}} \\
460.1 \mathrm{kN} \\
12.1 \%\end{array}$ & $\begin{array}{c}F_{\text {flange }} \\
1009.0 \mathrm{kN} \\
26.4 \%\end{array}$ & $\begin{array}{c}F_{\text {web }} \\
438.4 \mathrm{kN} \\
11.5 \%\end{array}$ \\
\hline $\begin{array}{l}\text { Tensile flange (bottom) } \\
\text { Tensile flange (top) } \\
\text { Tensile flange (top) } \\
\text { Rebar (tensile) }\end{array}$ & $\begin{array}{c}0.000335671 \\
0.003959609 \\
0.004206696 \\
0.00601\end{array}$ & Moment & $\begin{array}{c}M_{\mathrm{c}} \\
133.9 \mathrm{kN} \cdot \mathrm{m} \\
25.6 \%\end{array}$ & $\begin{array}{c}M_{\mathrm{t}}^{\prime} \\
28.9 \mathrm{kN} \cdot \mathrm{m} \\
5.5 \%\end{array}$ & $\begin{array}{c}M_{\text {flange }}^{\prime} \\
0.0 \mathrm{kN} \cdot \mathrm{m} \\
0.0 \%\end{array}$ & $\begin{array}{c}M_{\text {web }}^{\prime} \\
0.0 \mathrm{kN} \cdot \mathrm{m} \\
0.0 \%\end{array}$ & $\begin{array}{c}M_{\mathrm{t}} \\
134.3 \mathrm{kN} \cdot \mathrm{m} \\
25.7 \%\end{array}$ & $\begin{array}{c}M_{\text {flange }} \\
181.0 \mathrm{kN} \cdot \mathrm{m} \\
34.7 \%\end{array}$ & $\begin{array}{c}M_{\text {web }} \\
44.0 \mathrm{kN} \cdot \mathrm{m} \\
8.4 \%\end{array}$ \\
\hline
\end{tabular}

TABLE 6: Flexural moment capacity at the maximum load state (Specimen \#2) [19].

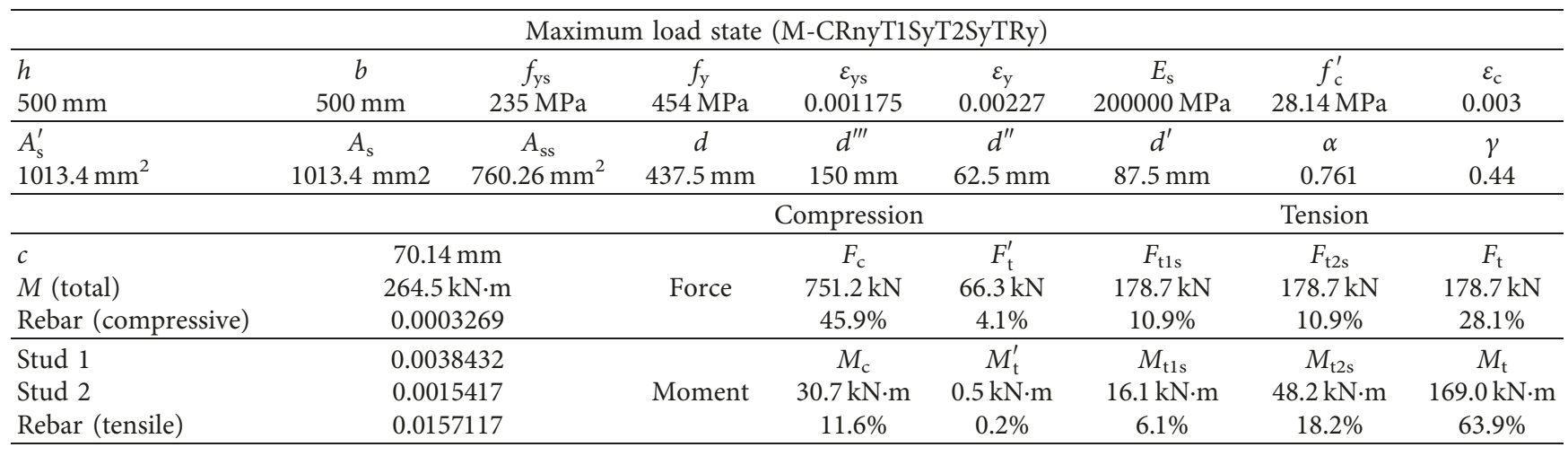


TABLe 7: Flexural moment capacity at the maximum load state (Specimen \#1) [19].

\begin{tabular}{|c|c|c|c|c|c|c|c|c|}
\hline \multicolumn{9}{|c|}{ Maximum load limit state (M-T1RnyT2Ry) } \\
\hline $\begin{array}{l}h \\
500 \mathrm{~mm} \\
\end{array}$ & $\begin{array}{c}b \\
500 \mathrm{~mm}\end{array}$ & & $\begin{array}{c}f_{\mathrm{y}} \\
454 \mathrm{MPa}\end{array}$ & & $\begin{array}{c}\mathcal{E}_{\mathrm{y}} \\
0.00227\end{array}$ & $\begin{array}{c}E_{\mathrm{s}} \\
200000 \mathrm{MPa}\end{array}$ & $\begin{array}{c}f_{\mathrm{c}}^{\prime} \\
28.14 \mathrm{MPa} \\
\end{array}$ & $\begin{array}{c}\mathcal{E}_{\mathrm{c}} \\
0.003\end{array}$ \\
\hline $\begin{array}{l}A_{\mathrm{s}}^{\prime} \\
1013.4 \mathrm{~mm}^{2}\end{array}$ & $\begin{array}{c}A_{\mathrm{s}} \\
1013.4 \mathrm{~mm}^{2}\end{array}$ & & $\begin{array}{c}d \\
437.5 \mathrm{~mm}\end{array}$ & $\begin{array}{c}d^{\prime \prime \prime} \\
150 \mathrm{~mm}\end{array}$ & $\begin{array}{c}d^{\prime \prime} \\
62.5 \mathrm{~mm}\end{array}$ & $\begin{array}{c}d^{\prime} \\
87.5 \mathrm{~mm}\end{array}$ & $\begin{array}{c}\alpha \\
0.761\end{array}$ & $\begin{array}{c}\gamma \\
0.41667\end{array}$ \\
\hline & & & \multicolumn{3}{|c|}{ Compression } & \multicolumn{3}{|c|}{ Tension } \\
\hline $\begin{array}{l}l c \\
M \text { (total) } \\
\text { Rebar (compressive) }\end{array}$ & $\begin{array}{c}53.06 \mathrm{~mm} \\
195.5 \mathrm{kN} \cdot \mathrm{m} \\
0.00053360\end{array}$ & Force $(\mathrm{kN})$ & \multicolumn{3}{|c|}{$\begin{array}{c}568.2 \mathrm{kN} \\
50.0 \%\end{array}$} & $\begin{array}{c}F_{\mathrm{t} 1} \\
108.1 \mathrm{kN} \\
9.5 \%\end{array}$ & \multicolumn{2}{|c|}{$\begin{array}{c}F_{\mathrm{t} 2} \\
460.1 \mathrm{kN} \\
40.5 \%\end{array}$} \\
\hline Rebar (tensile) & 0.020272 & Moment $(\mathrm{kN} \cdot \mathrm{m})$ & & $\begin{array}{c}M_{\mathrm{c}} \\
17.6 \mathrm{kN} \cdot \mathrm{m} \\
9.0 \%\end{array}$ & & $\begin{array}{c}M_{\mathrm{t} 1} \\
1.0 \mathrm{kN} \cdot \mathrm{m} \\
0.5 \%\end{array}$ & \multicolumn{2}{|c|}{$\begin{array}{c}M_{\mathrm{t} 2} \\
176.9 \mathrm{kN} \cdot \mathrm{m} \\
90.5 \%\end{array}$} \\
\hline
\end{tabular}

TABle 8: Comparison of analytical values to test data at the yield and maximum load state (units: $\mathrm{kN}$ and $\mathrm{kN} \cdot \mathrm{m}$ ) [19].

\begin{tabular}{|c|c|c|c|c|c|}
\hline \multirow{2}{*}{ Specimens } & \multirow{2}{*}{ Data } & \multicolumn{2}{|c|}{ Yield limit state } & \multicolumn{2}{|c|}{ Maximum load state } \\
\hline & & Load (moment) & Strain & Load (moment) & Strain \\
\hline \multirow{3}{*}{ Specimen \#1 } & Analytical & $125.3 \mathrm{kN}(188.0 \mathrm{kN} \cdot \mathrm{m})$ & 0.0022700 & $130.3 \mathrm{kN}(195.5 \mathrm{kN} \cdot \mathrm{m})$ & 0.0202700 \\
\hline & Experimental & $130.7 \mathrm{kN}(196.1 \mathrm{kN} \cdot \mathrm{m})$ & 0.0038640 & $136.8 \mathrm{kN}(205.2 \mathrm{kN} \cdot \mathrm{m})$ & 0.0011754 \\
\hline & Error & $4.0 \%$ & - & $5.0 \%$ & - \\
\hline \multirow{3}{*}{ Specimen \#2 } & Analytical & $162.9 \mathrm{kN}(244.3 \mathrm{kN} \cdot \mathrm{m})$ & 0.0022700 & $176.3 \mathrm{kN}(264.5 \mathrm{kN} \cdot \mathrm{m})$ & 0.0157100 \\
\hline & Experimental & $169.6 \mathrm{kN}(254.4 \mathrm{kN} \cdot \mathrm{m})$ & 0.0027120 & $195.9 \mathrm{kN}(293.9 \mathrm{kN} \cdot \mathrm{m})$ & 0.0042350 \\
\hline & Error & $4.1 \%$ & - & $11.1 \%$ & - \\
\hline \multirow{3}{*}{ Specimen \#3 } & Analytical & $287.2 \mathrm{kN}(430.8 \mathrm{kN} \cdot \mathrm{m})$ & 0.0022700 & $348.0 \mathrm{kN}(522.0 \mathrm{kN} \cdot \mathrm{m})$ & 0.0060000 \\
\hline & Experimental & $319.8 \mathrm{kN}(479.7 \mathrm{kN} \cdot \mathrm{m})$ & 0.0031820 & $354.3 \mathrm{kN}(531.5 \mathrm{kN} \cdot \mathrm{m})$ & 0.0038640 \\
\hline & Error & $11.4 \%$ & - & $1.8 \%$ & - \\
\hline
\end{tabular}

TABle 9: Analytical moment-strain relationship (Specimen \#1) [19].

\begin{tabular}{lccc}
\hline Limit state & $\begin{array}{c}\text { Moment } \\
(\mathrm{kN} \cdot \mathrm{m})\end{array}$ & $\begin{array}{c}\text { Rebar } \\
\text { strain }\left(\varepsilon_{\mathrm{t}}\right)\end{array}$ & $\begin{array}{c}\text { Neutral } \\
\text { axis }(\mathrm{mm})\end{array}$ \\
\hline & 38.80 & 0.000475 & 95.43 \\
Preyield limit state & 76.63 & 0.000940 & 96.27 \\
& 113.50 & 0.001395 & 37.13 \\
& 149.37 & 0.001838 & 98.02 \\
Yield limit state & 166.93 & 0.002055 & 98.47 \\
\hline & 187.95 & 0.002270 & 98.83 \\
\hline Postyield limit state & 186.25 & 0.003298 & 85.41 \\
& 188.37 & 0.004964 & 73.36 \\
& 191.90 & 0.009467 & 59.84 \\
& 193.37 & 0.012169 & 56.38 \\
& 194.44 & 0.014768 & 54.47 \\
Maximum load limit state & 195.10 & 0.017212 & 53.54 \\
\hline
\end{tabular}

critical section of Specimen \#2 shown in Figure 5(b), an error of less than $8 \%$ was obtained compared with test data based on analytical equations at the yield and maximum load limit states. The neutral axes of the specimen having hybrid joints with headed studs predicted by the analytical equilibrium equations proposed in this study were used to calculate flexural moment capacity at the maximum load limit state.
TABle 10: Analytical moment-strain relationship (Specimen \#2) [19].

\begin{tabular}{lccc}
\hline & $\begin{array}{c}\text { Moment } \\
(\mathrm{kN} \cdot \mathrm{m})\end{array}$ & $\begin{array}{c}\text { Rebar } \\
\text { strain }\left(\varepsilon_{\mathrm{t}}\right)\end{array}$ & $\begin{array}{c}\text { Neutral } \\
\text { axis }(\mathrm{mm})\end{array}$ \\
\hline & 52.46 & 0.000459 & 117.33 \\
Preyield limit state & 103.17 & 0.000906 & 118.52 \\
& 152.09 & 0.001341 & 119.76 \\
& 198.49 & 0.001775 & 120.37 \\
& 222.14 & 0.002024 & 119.19 \\
\hline Yield limit state & 244.31 & 0.002270 & 118.40 \\
\hline & 241.56 & 0.002561 & 113.75 \\
Postyield limit state & 251.63 & 0.004136 & 98.37 \\
& 260.43 & 0.005732 & 90.74 \\
& 262.38 & 0.007071 & 84.79 \\
& 262.96 & 0.007767 & 82.31 \\
Maximum load limit state & 264.19 & 0.009853 & 76.86 \\
& 264.44 & 0.010534 & 75.58 \\
\hline
\end{tabular}

Through this study, equilibria of all possible stress states were investigated to locate neutral axes, as shown in Tables 5-7, and the correct stress state was identified with neutral axes, as shown in Figure 5. Steel and headed studs embedded into the column base to anchor the steel section to the column base (i.e., Specimen \#2), which allows for an efficient assembly, with speed similar to that of the erection 
TABLE 11: Analytical moment-strain relationship (Specimen \#3) [19].

\begin{tabular}{lccc}
\hline Limit state & Moment $(\mathrm{kN} \cdot \mathrm{m})$ & Rebar strain $\left(\varepsilon_{\mathrm{t}}\right)$ & Neutral axis $(\mathrm{mm})$ \\
\hline & 95.84 & 0.000495 & 153.66 \\
& 186.14 & 0.000971 & 155.70 \\
Preyield limit state & 270.74 & 0.001425 & 157.84 \\
& 349.47 & 0.001858 & 160.09 \\
& 386.57 & 0.002067 & 161.26 \\
\hline Yield limit state & 430.80 & 0.002270 & 162.46 \\
\hline & 442.98 & 0.002462 & 162.17 \\
Postyield limit state & 470.28 & 0.002718 & 162.10 \\
& 496.14 & 0.003258 & 158.45 \\
& 504.59 & 0.003629 & 155.43 \\
& 509.07 & 0.003874 & 153.78 \\
Maximum load limit state & 513.93 & 0.005192 & 147.84 \\
\hline
\end{tabular}

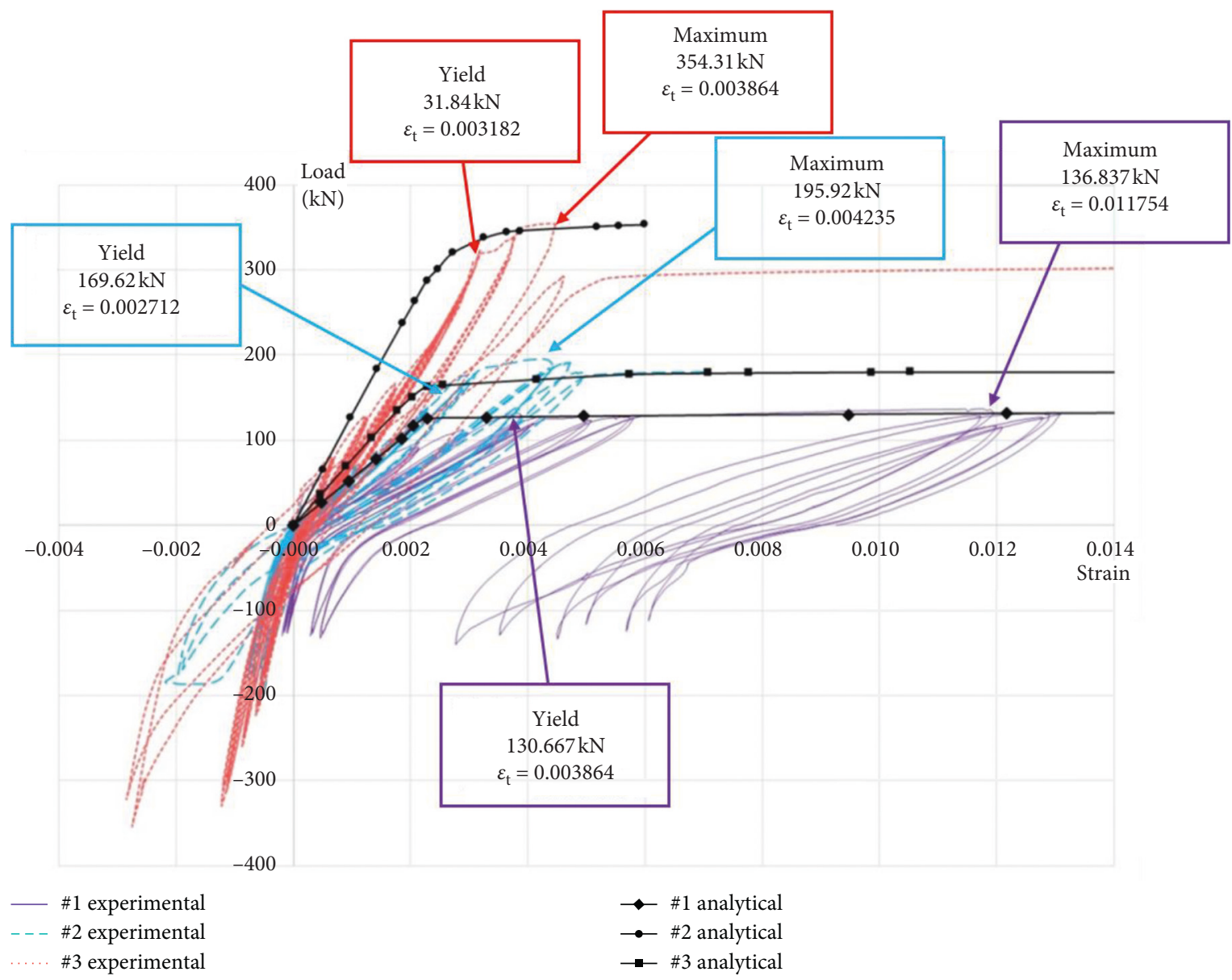

Figure 6: Comparison of analytical load-strain relationships with test data from Strain Gauge \#20 [17, 19].

of steel frames, were verified to increase the flexural structural performance of concrete columns. An analytical comparison of concrete columns with and without steel sections at the column joints and a column with a steel section throughout its entire length demonstrated that the headed studs installed on the steel joints improved the flexural capacity of the concrete columns, ductile behavior, and crack patterns. The average contribution of the headed studs to the total resistance of the column (Specimen \#2) was as large as $12.2 \%$ at the maximum load limit state, whereas the strength provided by the tensile rebar decreased from 90.5\% (Table 7) for Specimen \#1 to 63.9\% (Table 6) for Specimen $\# 2$, demonstrating that the strength contributed by hybrid joints and headed studs can reduce the 
dependence on rebars. The flexural strength of Specimen \#1 increased by $30 \%$ and $35 \%$ at the yield limit state and maximum load limit state, respectively, when steel sections and headed studs were installed in the joint. In Specimen \#2, the hybrid joint containing a steel section with headed studs at the concrete column connection, which was inserted primarily to facilitate the erection of the frame, was found to increase the flexural strength relative to a conventional concrete column.

\section{Data Availability}

The data used to support the findings of this study are available from the corresponding author upon request.

\section{Conflicts of Interest}

The authors declare that they have no conflicts of interest.

\section{References}

[1] T. M. Sheikh, G. G. Deierlein, J. A. Yura, and J. O. Jirsa, "Beam-column moment connections for composite frames: part 1," Journal of Structural Engineering, vol. 115, no. 11, pp. 2858-2876, 1989.

[2] J. Men, Z. Guo, and Q. Shi, "Experimental research on seismic behavior of novel composite RCS joints," Steel and Composite Structures, vol. 19, no. 1, pp. 209-221, 2015.

[3] H. Ma, W. Jiang, and C. Cho, "Experimental study on two types of new beam-to-column connections," Steel \& Composite Structures, vol. 11, no. 4, pp. 291-305, 2011.

[4] H. Jiang, Q. Li, W. Jiang, and D. Y. Zhang, "Study on seismic performance of connection joint between prefabricated prestressed concrete beams and high strength reinforcementconfined concrete columns," Journal of steel and composite structures, vol. 21, no. 2, pp. 343-356, 2015.

[5] X. Liang and G. J. Parra-Montesinos, "Seismic behavior of reinforced concrete column-steel beam subassemblies and frame systems," Journal of Structural Engineering, vol. 130, no. 2, pp. 310-319, 2004.

[6] G. Parra-Montesinos and J. K. Wight, "Modeling shear behavior of hybrid RCS beam-column connections," Journal of Structural Engineering, vol. 127, no. 1, pp. 3-11, 2001.

[7] W. Salvatore, O. S. Bursi, and D. Lucchesi, "Design, testing and analysis of high ductile partial-strength steel-concrete composite beam-to-column joints," Computers \& Structures, vol. 83, no. 28-30, pp. 2334-2352, 2005.

[8] Y. Tagawa, B. Kato, and H. Aoki, "Behavior of composite beams in steel frame under hysteretic loading," Journal of Structural Engineering, vol. 115, no. 8, pp. 2029-2045, 1989.

[9] C. D. Annan, M. A. Youssef, and M. H. El Naggar, "Experimental evaluation of the seismic performance of modular steel-braced frames," Engineering Structures, vol. 31, no. 7, pp. 1435-1446, 2009.

[10] Q. Wang, Q. Shi, and H. Tian, "Seismic behavior of steel reinforced concrete (SRC) joints with new-type section steel under cyclic loading," Steel and Composite Structures, vol. 19, no. 6, pp. 1561-1580, 2015.

[11] G. J. Parra-Montesinos, X. Liang, and J. K. Wight, "Towards deformation-based capacity design of RCS beam-column connections," Engineering Structures, vol. 25, no. 5, pp. 681690, 2003.
[12] A. Braconi, W. Salvatore, R. Tremblay, and O. S. Bursi, "Behaviour and modelling of partial-strength beam-tocolumn composite joints for seismic applications," Earthquake Engineering \& Structural Dynamics, vol. 36, no. 1, pp. 142-161, 2006.

[13] O. S. Bursi, F.-F. Sun, and S. Postal, "Non-linear analysis of steel-concrete composite frames with full and partial shear connection subjected to seismic loads," Journal of Constructional Steel Research, vol. 61, no. 1, pp. 67-92, 2005.

[14] S. S. F. Mehanny and G. G. Deierlein, Modeling of assessment of seismic performance of composite frames with reinforced concrete columns and steel beams, Ph.D. Dissertation, Stanford University, Stanford, CA, USA, 2000, http://www. researchgate.net/publication/34190170.

[15] R. Bjorhovde, A. Colson, and J. Brozzetti, "Classification system for beam-to-column connections," Journal of Structural Engineering, vol. 116, no. 11, pp. 3059-3076, 1990.

[16] G. G. Deierlein, T. M. Sheikh, J. A. Yura, and J. O. Jirsa, "Beam-column moment connections for composite frames: Part 2," Journal of Structural Engineering, vol. 115, no. 11, pp. 2877-2896, 1989.

[17] J. Kim, W.-K. Hong, and J.-H. Kim, "Experimental investigation of the influence of steel joints upon the flexural capacity of precast concrete columns," Structural Design of Tall and Special Buildings, vol. 26, no. 5, p. e1340, 2016.

[18] AISC/ANSI 341-05, Seismic Provisions for Structural Steel Buildings, American Institute of Steel Construction, Chicago, IL, USA, 2005.

[19] J. H. Kim, "Experimental and analytical investigation of column-beam joints with hybrid frame based on strain compatibility," Master's thesis, Kyung Hee University, Seoul, South Korea, 2014.

[20] R. Park and T. Paulay, Reinforced Concrete Structures, John Wiley \& Sons, Inc., Hoboken, NJ, USA, 1975. 


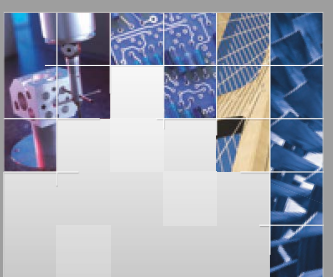

\section{Enfincering}
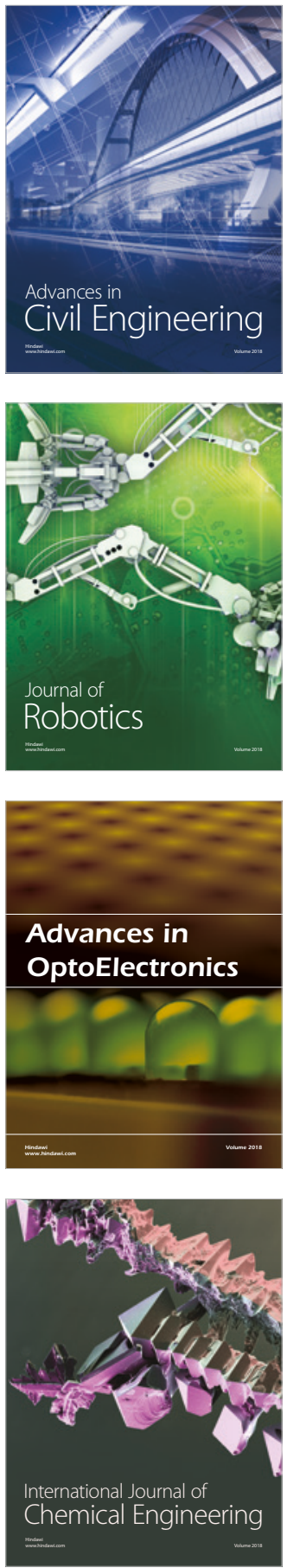

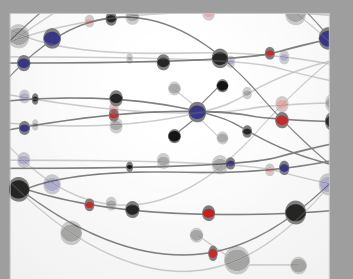

\section{Rotating \\ Machinery}

The Scientific World Journal

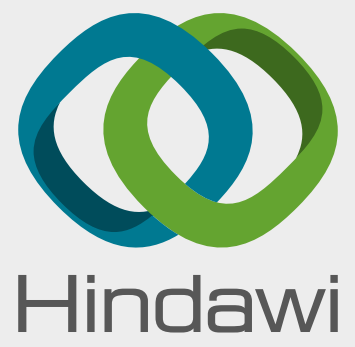

Submit your manuscripts at

www.hindawi.com
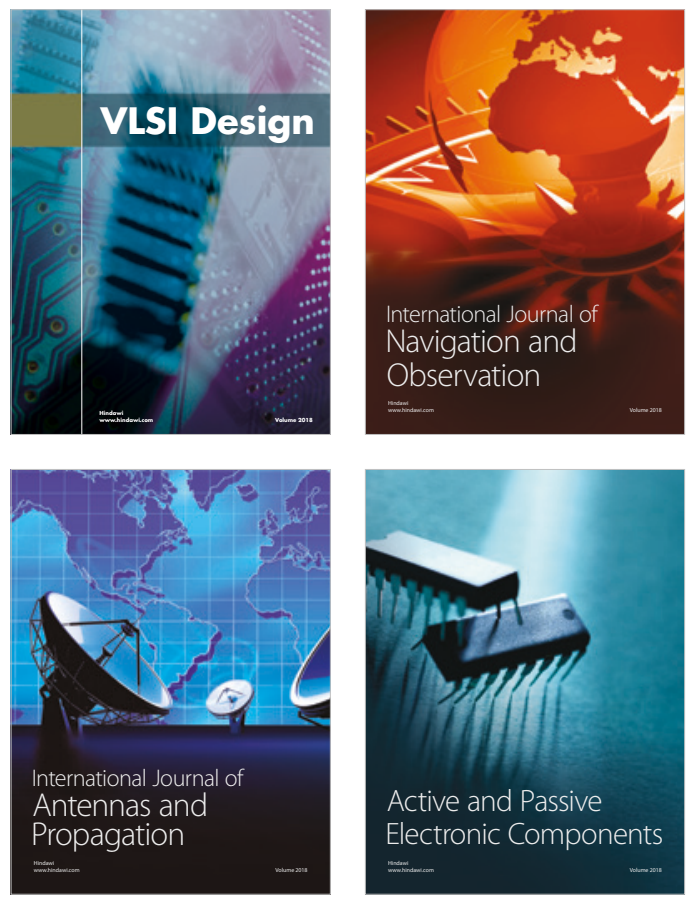
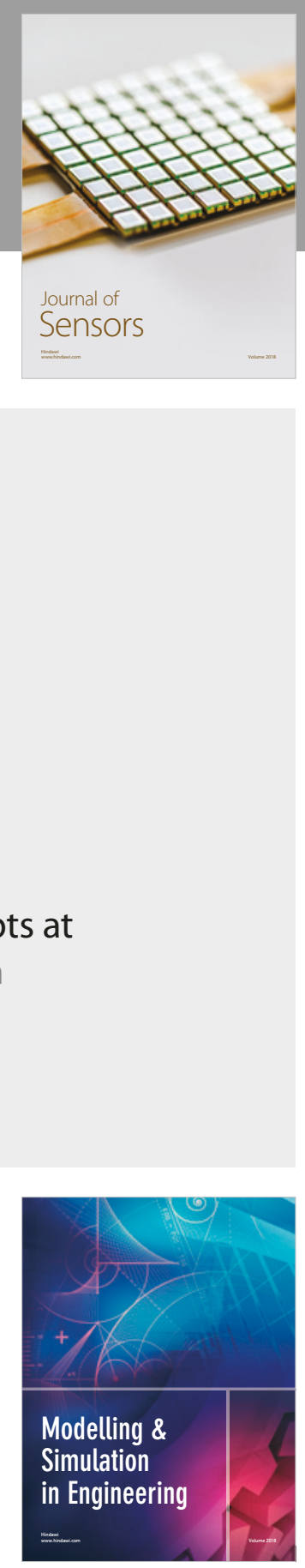

\section{Advances \\ Multimedia}
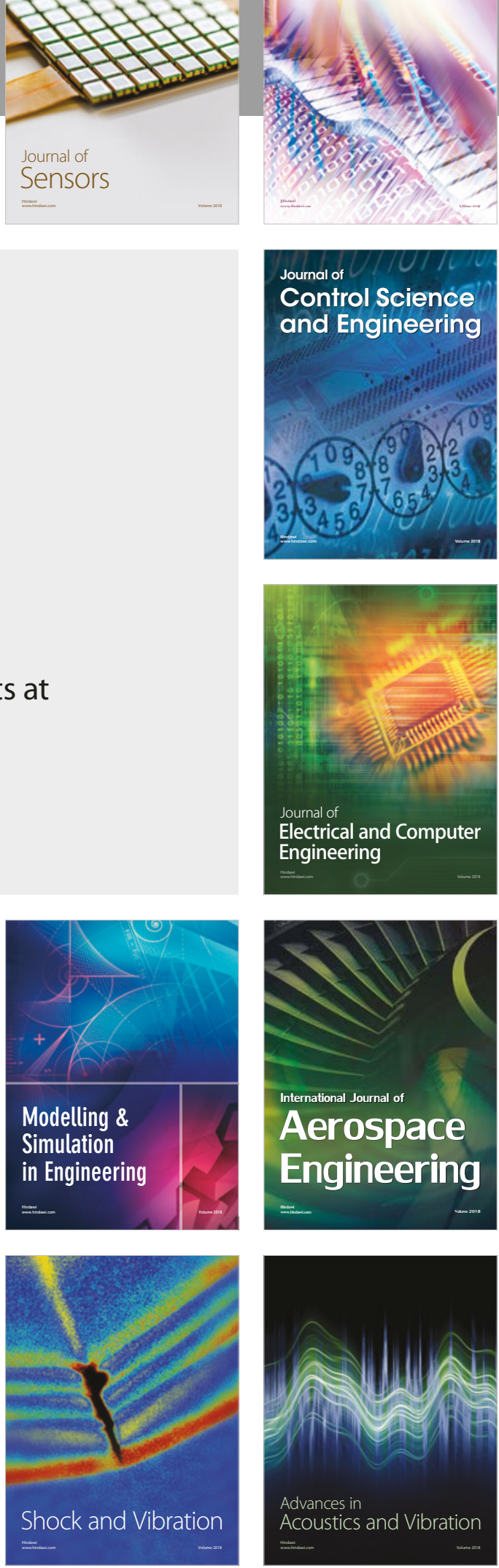